\title{
HUBUNGAN FAKTOR DEMOGRAFI DAN DUKUNGAN SOSIAL DENGAN DEPRESI PASCASALIN
}

\author{
Nurfatimah $^{1}$, Christina Entoh ${ }^{1}$ \\ ${ }^{1}$ Prodi D-III Kebidanan Poso, Poltekkes Kemenkes Palu \\ Email :nfatimahhh@gmail.com
}

\begin{abstract}
ABSTRAK
Depresi pascasalin adalah gangguan mental yang terjadi pada pascasalin dan dapat berlangsung sampai satu tahun. Gangguan mood pada ibu pascasalin bukan persoalan yang mudah. Dampaknya bisa memporakporandakan kehidupan ibu dan anaknya. Saat ini masih banyak ibu yang mengalami depresi pascasalin tetapi belum terdeteksi. Tidak semua ibu merasa gembira dengan kelahiran mereka, misalnya ibu mengungkapkan tidak bisa tidur dengan nyenyak dan mengalami penurunan berat badan. Tujuan penelitian ini untuk menganalisis hubungan antara faktor demografi dan dukungan sosial dengan depresi pascasalin di wilayah kerja Puskesmas Kayamanya. Desain dalam penelitian ini adalah cross sectional. Sampel penelitian sebanyak 56 responden yang diikuti mulai dari awal kelahiran sampai tujuh hari pascasalin. Pemilihan sampel dilakukan dengan menggunakan teknik consequtive sampling. Instrumen yang digunakan dalam penelitian ini adalah Edinburgh Postnatal Depression Scale (EPDS) dan kuesioner social support yang sudah baku. Hasil penelitian menunjukkan bahwa umur tidak berhubungan secara signifikan dengan depresi pascasalin $(p=0,514)$ dan pendidikan $(\mathrm{p}=0,154)$, sedangkan paritas $(\mathrm{p}=0,012)$, status ekonomi $(\mathrm{p}=0,030)$, dukungan sosial meliputi keluarga $(\mathrm{p}=0,035)$, teman $(\mathrm{p}=0,017)$, dan bidan $(\mathrm{p}=0,005)$ yang berarti memiliki hubungan yang signifikan. Analisis multivariat menunjukkan bahwa dukungan bidan (wald $=4,236 ; p=0,040$ ) merupakan faktor yang paling dominan berhubungan dengan depresi pascasalin.
\end{abstract}

Kata Kunci: faktor demografi, dukungan sosial, depresi pascasalin

\begin{abstract}
Postnatal depression is a mental disorder after the birth of her child and can last up to one year. Maternal postnatal mood disorder not an easy matter. The impact can be devastating life of the mother and her child. Currently there are many women who experienced postnatal depression but has not been detected. But, they are not ready due to the unwell sleep and weigh loss. The purpose of this study was to analyze the relationship between demographic factors and social support in postnatal depression in The Working Area Of Puskesmas Kayamanya.The design of this research is cross sectional. Research subjects were followed for 56 respondents ranging from childbirth to seven days postnatal. The samples was chosen by using consequtive sampling. The instruments used in this research are the Edinburgh Postnatal Depression Scale (EPDS) and standard social support questionnaire. The results reveal that the age is not significantly associated with depression postnatal $(\mathrm{p}=0.514)$ and education $(\mathrm{p}=0.154)$; but it is significantly parity $(\mathrm{p}=0.012)$; economic status $(\mathrm{p}=$ $0.030)$, social support include the family $(\mathrm{p}=0.035)$; friends $(\mathrm{p}=0.017)$; and midwives $(\mathrm{p}=0.005)$. The multivariate analysis reveals that midwifes support (wald $=4,236 ; p=0,04$ ) is the dominant factor causing postnatal depression.
\end{abstract}


Keywords: demographic factors, social support, postnatal depression

\section{PENDAHULUAN}

Depresi merupakan gangguan suasana perasaan (mood) yang dialami seseorang dan mempunyai gejala diantaranya kehilangan minat dan kegembiraan, kekurangan energi, insomnia, gelisah dan rasa lelah. Kejadian depresi pada seorang wanita memiliki prevalensi yang tinggi terutama pada usia subur, termasuk pada saat kehamilan dan dapat bertahan sampai periode pascasalin. ${ }^{1}$ Depresi pascasalin adalah depresi yang bervariasi dari hari ke hari dengan menunjukkan kelelahan, mudah marah dan gangguan nafsu makan. ${ }^{2}$ Gangguan mental yang berupa depresi pascasalin merupakan salah satu perubahan psikologis yang terjadi pada masa nifas dan dapat berlangsung sampai satu tahun.

Prevalensi kejadian depresi pascasalin di negara-negara industri sekitar $13-20 \%$ pada semua wanita. Sebuah penelitian di Australia menemukan 15,5\% wanita memiliki gejala depresi pascasalin. ${ }^{3}$ Montazeri dalam penelitiannya terhadap 100 perempuan di Iran menunjukkan kejadian depresi pascasalin sebesar 22\% pada 6-8 minggu dan $18 \%$ pada $12-14$ minggu setelah melahirkan. ${ }^{4}$ Hasil penelitian yang dilakukan pada ibu bersalin di Rumah Sakit Umum Gunung Sitoli dan lima Puskesmas di Kabupaten Nias menunjukkan angka kejadian depresi sebesar $51,1 \%{ }^{5}$

Beberapa fenomena yang terjadi di Puskesmas Kayamanya Kabupaten Poso, tidak semua ibu merasa gembira ketika anaknya lahir, misalnya ibu mengungkapkan tidak bisa tidur dengan nyenyak dan mengalami penurunan berat badan yang disertai tidak nafsu makan. Hasil penelitian yang dilakukan oleh Fatmah Ibrahim dan Muhamad Ikhsan kepada 76 ibu postpartum di Rumah Sakit Ibu dan Anak Pertiwi Makasar pada tahun 2012, terdapat 19,7\% mengalami depresi setelah melahirkan. ${ }^{6}$ Permasalahan diatas didukung dengan hasil survei pendahuluan yang dilakukan dengan memberikan kuisioner kepada 10 ibu setelah melahirkan di Puskesmas Kayamanya, didapatkan hasil tujuh ibu mengalami depresi ringan dan tiga ibu mengalami depresi sedang.

Tingginya angka kejadian depresi baik pada kehamilan maupun pascasalin dipengaruhi oleh banyak hal, diantaranya adalah status ekonomi, dukungan sosial, kecemasan sebelum dan selama kehamilan, kehamilan yang tidak dinginkan serta faktor demografi yang meliputi umur, pendidikan, paritas ${ }^{.7}$ Faktor ekonomi juga dapat mempengaruhi kejadian depresi perinatal, karena status ekonomi suatu keluarga mempengaruhi kesejahteraan ibu dan janin seperti gizi, perawatan yang diterima serta jaminan untuk kelangsungan hidup selanjutnya. Status sosial ekonomi terbukti berhubungan dengan kejadian depresi pada akhir periode kehamilan, dua dan tiga bulan pascasalin, selain itu ibu dengan pendapatan yang rendah, pendidikan rendah, tidak bekerja dan belum menikah memiliki risiko 11 kali untuk terjadi depresi kehamilan dan pascasalin dibandingkan ibu dengan status sosial ekonomi baik. $^{8,9}$

Dukungan sosial juga mempengaruhi kejadian depresi baik pada 
kehamilan maupun pascasalin. ${ }^{10}$ Dukungan sosial sejak kehamilan terbukti mempengaruhi kejadian depresi. ${ }^{7}$ Berdasarkan penelitian yang dilakukan di Medan menunjukkan bahwa terdapat hubungan yang signifikan antara pendidikan ibu $(\mathrm{p}=0,003)$, paritas $\mathrm{ibu}$ $(0,016)$, dan dukungan suami $(0,000)$ terhadap depresi pascasalin. ${ }^{11}$

Depresi pada ibu pascasalin juga terbukti berhubungan dengan gangguan perkembangan kognitif dan hubungan kelekatan yang aman antara ibu dan anak. ${ }^{3}$ Wanita dengan depresi pascasalin juga cenderung untuk menghentikan pemberian ASI dan perkembangan kognitif anak juga terbukti terganggu karena kurangnya interaksi ibu dan bayi. ${ }^{12}$ Efek jangka panjang dari depresi juga akan berpengaruh pada keluarga dan masyarakat, terutama perkembangan anak yaitu kognitif, emosional, sosial dan perilaku. Sehingga perlu dilakukan pemeriksaan dan deteksi dini dari faktor risiko yang ada untuk memungkinkan pemberian intervensi segera untuk mengatasinya.

\section{METODE PENELITIAN}

Penelitian ini dilakukan di wilayahkerja Puskesmas Kayamanya Kabupaten Poso. Jenis penelitian yang digunakan adalah Penelitian Obsevasional Analitik dengan rancangan Cross Sectional Study. Populasi dalam penelitian ini adalah semua ibu nifas yang berada di wilayah kerja Puskesmas Kayamanya Kabupaten Poso. Sampel dalam penelitian ini adalah sebagian ibu nifas yang berada di wilayah kerja Puskesmas Kayamanya Kabupaten Poso dengan kriteria sebagai berikut bayi yang dilahirkan tunggal dan aterm, berat badan lahir $\geq 2500$ gram, Persalinan normal tanpa komplikasi/tindakan, dan Ibu nifas tanpa komplikasi.

Peneliti menggunakan teknik Consecutive Sampling. Teknik ini merupakan pemilihan sampel dengan dengan menetapkan subjek yang memenuhi kriteria penelitian dimasukan dalam penelitian sampai kurun waktu tertentu, sehingga jumlah klien yang dibutuhkan terpenuhi. Peneliti menunggu responden yang datang memeriksakan diri ke Puskesmas sampai jumlah yang diinginkan terpenuhi yaitu 56 orang, sesuai dengan kriteria inklusi dan dalam waktu tiga bulan yang telah ditentukan peneliti.

Instrumen pengumpulan data yang digunakan dalam penelitian ini adalah kuesioner Multidimensional Scala of Perceived Sosial Support (MSPSS) yang merupakan alat ukur untuk mengkaji dukungan social yang diterima seseorang. MPSS merupakan kuesioner yang dapat diisi dengan mudah oleh subjek dan terdiri dari 12 pertanyaan. Sistem penilaian pada kuesioner dengan menggunakan skala likert. Setiap pertanyaan terdiri dari lima pilihan pertanyaan yang dimulai dari sangat tidak setuju dengan skor 1 sampai pilihan sangat setuju dengan skor 5 .

Pengukuran depresi menggunakan Edinburgh Postnatal Depression Scale (EPDS).Alat ukur depresi ini sudah divalidasi ke dalam bahasa Indonesia, terdiri dari 10 pertanyaan yang berisi tentang anhedonia (pertanyaan 1 dan 2), kecemasan (pertanyaan 3,4,5,6 dan 7) dan depresi (pertanyaan 8,9 dan 10). Skor di atas 12 memiliki kemungkinan untuk risiko terjadinya depresi pada ibu pascasalin. Apabila skor kurang dari 12, bidan dapat memberikan asuhan kepada ibu pascasalin untuk mengatasi permasalahan yang dihadapi, sedangkan 
jika skor lebih dari 12 ibu dapat merujuk ke psikolog dan apabila sudah terdiagnosa depresi dapat dirujuk kepada psikiatri. Analisis data pada penelitian ini terdiri atas analisis univariate, bivariat dan multivariat dengan regresi logistik.

\section{HASIL PENELITIAN}

\section{Analisis Univariat}

Tabel 1 menunjukkan bahwa dari 56 orang responden, kelompok umur terbanyak berusia 20-35 tahun sebanyak 52 orang $(92,9 \%)$, memiliki pendidikan SMA/sederajat sebanyak 28 orang $(50 \%)$, multipara sebanyak 40 orang $(71,4 \%)$ dan memiliki status ekonomi tinggi sebanyak 32 orang $(57,1 \%)$. Dukungan sosial pada masa pascasalin dikategorikan tinggi sebesar 76,8\%, dukungan sosial terendah adalah diberikan oleh bidan yaitu sebanyak 37 orang $(66,1 \%)$. Dari 56 orang responden, mayoritas responden yang diukur pada pascasalin dikategorikan tidak berisiko sebanyak 47 orang $(83,9 \%)$.

Tabel 1. Distribusi Frekuensi Berdasarkan Umur Ibu, Pendidikan, Paritas, Penghasilan, Dukungan Keluarga, Dukungan Teman, Dukungan Bidan, dan Depresi Pascasalin di Wilayah Kerja Puskesmas Kayamanya

\begin{tabular}{llll}
\hline \multicolumn{1}{c}{ Variabel } & \multicolumn{1}{c}{ Kategori } & N & \multicolumn{1}{c}{$\%$} \\
\hline Faktor Demografi & & & \\
Umur Ibu & $<20$ tahun & 1 & 1,8 \\
& $20-35$ tahun & 52 & 92,9 \\
\multirow{2}{*}{ Pendidikan } & $>35$ tahun & 3 & 5,4 \\
& SD & 9 & 16,1 \\
& SMP & 6 & 10,7 \\
& SMA & 28 & 50,0 \\
Paritas & PT/AK & 13 & 23,2 \\
& Primipara & 16 & 28,6 \\
Status Ekonomi & Multipara & 40 & 71,4 \\
& Tinggi & 32 & 57,1 \\
Dukungan Sosial & Rendah & 24 & 42,9 \\
Dukungan Keluarga & Tinggi & 42 & 75,0 \\
& Rendah & 14 & 25,0 \\
Dukungan Teman & Tinggi & 39 & 69,6 \\
& Rendah & 17 & 30,4
\end{tabular}

\begin{tabular}{llll} 
Dukungan Bidan & Tinggi & 37 & 66,1 \\
& Rendah & 19 & 33,9 \\
Depresi Pascasalin & Berisiko & 9 & 16,1 \\
& Tidak & 47 & 83,9 \\
& berisiko & & \\
\hline
\end{tabular}

\section{Analisis Bivariat}

Tabel 2 menunjukkan faktor yang berhubungan dengan depresi pascasalin adalah faktor paritas $(\mathrm{p}=0,012)$ dan faktor status ekonomi $(p=0,030)$. Sedangkan faktor umur dan pendidikan tidak berhubungan dengan depresi pascasalin dengan nilai $\mathrm{p}>0,05$. Depresi pascasalin lebih berisiko oleh ibu yang dukungan keluarganya rendah $(35,7 \%)$ daripada tinggi dukungan keluarganya $(9,5 \%)$. Sedangkan depresi pascalin tidak berisiko pada ibu yang dukungan keluarganya tinggi (90,5\%) dibanding ibu yang dukungan keluarganya rendah (64,3\%).

Tabel 2. Hubungan Faktor Demografi dengan Depresi Pascasalin di Wilayah Kerja Puskesmas Kayamanya

\begin{tabular}{|c|c|c|c|c|c|}
\hline \multirow{4}{*}{$\begin{array}{l}\text { Faktor } \\
\text { Demografi }\end{array}$} & \multicolumn{4}{|c|}{ Depresi Pascasalin } & \multirow{4}{*}{$\begin{array}{l}\text { Nilai } p^{*} \\
\text { OR }(95 \% \mathrm{CI})\end{array}$} \\
\hline & \multirow{2}{*}{\multicolumn{2}{|c|}{ Risiko }} & \multirow{2}{*}{\multicolumn{2}{|c|}{$\begin{array}{l}\text { Tidak } \\
\text { Risiko }\end{array}$}} & \\
\hline & & & & & \\
\hline & $\mathrm{n}$ & $\%$ & $\mathrm{n}$ & $\%$ & \\
\hline \multicolumn{6}{|l|}{ Umur } \\
\hline$<20$ dan $>$ & 1 & 25,0 & 3 & 75,0 & \multirow{4}{*}{$\begin{array}{l}\mathrm{p}=0,514 \\
1,8(0,2-19,9)\end{array}$} \\
\hline 35 thn & & & & & \\
\hline $20-35$ thn & 8 & 15,4 & 44 & 84,6 & \\
\hline \multicolumn{5}{|l|}{ Pendidikan } & \\
\hline Dasar & 2 & 13,3 & 13 & 86,7 & \multirow{3}{*}{$\begin{array}{l}\mathrm{p}=0,154 \\
1,2(0,1-9,9) \\
1,4(0,2-8,3)\end{array}$} \\
\hline Menengah & 5 & 17,9 & 23 & 82,1 & \\
\hline Tinggi & 2 & 15,4 & 11 & 84,6 & \\
\hline \multicolumn{6}{|l|}{ Paritas } \\
\hline Primipara & 6 & 37,5 & 10 & 62,5 & \multirow{2}{*}{$\begin{array}{l}p=0,012 \\
7,4(1,6-34,9)\end{array}$} \\
\hline Multipara & 3 & 7,5 & 37 & 92,5 & \\
\hline \multicolumn{6}{|c|}{ Status Ekonomi } \\
\hline Rendah & 7 & 29,2 & 17 & 70,8 & \multirow{2}{*}{$\begin{array}{l}\mathrm{p}=0,030 \\
6,2(1,2-33,2)\end{array}$} \\
\hline Tinggi & 2 & 6,3 & 30 & 93,8 & \\
\hline
\end{tabular}

*Nilai $\mathrm{p}$ dihitung menggunakan uji chi square 
Tabel 3. Hubungan Dukungan Sosial Dengan Depresi Pascasalin di Wilayah Kerja Puskesmas Kayamanya

\begin{tabular}{|c|c|c|c|c|c|}
\hline \multirow{3}{*}{$\begin{array}{l}\text { Dukungan } \\
\text { Sosial }\end{array}$} & \multicolumn{4}{|c|}{ Depresi Pascasalin } & \multirow{3}{*}{$\begin{array}{ll}\mathrm{p}^{*} & \\
\text { OR } & (95 \% \\
\mathrm{CI}) & \end{array}$} \\
\hline & \multicolumn{2}{|c|}{ Risiko } & \multicolumn{2}{|c|}{ Tidak Risiko } & \\
\hline & $\mathrm{n}$ & $\%$ & $\mathrm{n}$ & $\%$ & \\
\hline Keluarga & & & & & $p=0,035$ \\
\hline Rendah & 5 & 35,7 & 9 & 64,3 & $5,3 \quad(1,2-$ \\
\hline Tinggi & 4 & 9,5 & 38 & 90,5 & $23,7)$ \\
\hline Teman & & & & & $\mathrm{p}=0,017$ \\
\hline Rendah & 6 & 35,3 & 11 & 64,7 & $6,5 \quad(1,4-$ \\
\hline Tinggi & 3 & 7,7 & 36 & 92,3 & $30,6)$ \\
\hline Bidan & & & & & $\mathrm{p}=0,005$ \\
\hline Rendah & 6 & 37,5 & 10 & 62,5 & $10,2 \quad(1,9-$ \\
\hline Tinggi & 3 & 7,5 & 37 & 92,5 & $56,0)$ \\
\hline
\end{tabular}

*Nilai p dihitung menggunakan uji chi square

Risiko depresi pascasalin lebih besar dialami oleh ibu yang dukungan temannya rendah $(35,3 \%)$ dibanding dukungan temannya tinggi $(7,7 \%)$. Sedangkan depresi pascasalin tidak berisiko lebih besar dialami oleh ibu yang dukungan temannya tinggi (92,3\%) dibanding dukungan teman yang rendah (64,7\%). Hubungan antara dukungan bidan dengan depresi pascasalin pada Tabel 3, menunjukkan bahwa ibu nifas yang mengalami depresi pascasalin lebih besar dialami oleh ibu yang rendah mendapatkan dukungan dari bidan (37,5\%) daripada yang tinggi dukungan bidan (7,5\%). Sedangkan ibu yang tidak berisiko mengalami depresi pascasalin lebih besar dialami pada ibu yang didukung oleh bidan $(92,5 \%)$ dibanding ibu yang tidak didukung oleh bidan (62,5\%).

\section{Analisis Multivariat}

Tabel 4. Final Model analisis Regresi Logistik Berganda Depresi Pascasalin di Wilayah Kerja PKM Kayamanya

\begin{tabular}{llll}
\hline Variabel & Wald & P & OR $(95 \%$ CI $)$ \\
\hline $\begin{array}{l}\text { Paritas } \\
\begin{array}{l}\text { Dukungan } \\
\text { bidan }\end{array}\end{array}$ & 2,766 & 0,096 & $4,2(0,8-22,3)$ \\
\hline
\end{tabular}

Berdasarkan hasil analisis regresi logistik berganda pada tabel 4 menunjukkan bahwa paritas dan dukungan bidan memiliki hubungan bermakna secara statistik. Hal ini dapat dilihat dari nilai statistik uji Wald yang mempunyai nilai signifikan value lebih kecil dari 0,05. Dari hasil nilai statistik wald didapatkan bahwa secara berurut paritas (wald $=2,766$; $\mathrm{p}=0,096$ ) kemudian dukungan bidan (wald $=4,236 ; \mathrm{p}=0,04)$ merupakan faktor paling dominan berhubungan dengan depresi pascasalin. Berdasarkan nilai odds ratio (OR), dapat diketahui bahwa variabel yang dominan dengan depresi pascasalin adalah variabel dukungan bidan, dimana ibu nifas memiliki kecenderungan mengalami depresi pascasalin 6,58 kali lebih besar dibanding ibu nifas yang tidak mendapat dukungan dari bidan.

\section{PEMBAHASAN}

\section{Hubungan Faktor Demografi dengan Depresi Pascasalin}

Hubungan faktor demografi dengan depresi pascasalin pada penelitian ini ditunjukkan pada tabel 2, berdasarkan tabel tersebut terlihat bahwa faktor paritas dan sosial ekonomi berhubungan dengan depresi pascasalin. Wanita yang baru pertama kalimelahirkan lebih umum menderita depresi karena setelah melahirkan wanita tersebut berada dalam proses adaptasi, kalau dulu hanya memikirkan diri sendiri, begitu bayi lahir jika ibu tidak paham peran barunya, dia akan menjadi bingung sementara bayinya harus tetap dirawat, sedangkan ibu yang sudah pernah beberapa kali melahirkan secara psikologis lebih siap menghadapi kelahiran bayinya dibandingkan dengan ibu yang baru pertama kali. 
Hasil penelitian ini menunjukkan bahwa responden yang paling banyak berisiko mengalami depresi pascasalin adalah primipara sebanyak enam orang (37,5\%). Hal ini sejalan dengan penelitian yang dilakukan di RS Margono Soekardjo Purwokerto tentang risiko depresi post partum pada ibu yang baru pertama kali dan yang sudah beberapa kali melahirkan didapatkan bahwa mayoritas risiko depresi postpartum dialami oleh ibu yang baru pertama kali melahirkan. ${ }^{13}$ Hasil penelitian yang sama dilakukan di RSU dr. Pirngadi, Medan, didapatkan bahwa terdapat pengaruh signifikan paritas ibu terhadap depresi postpartum. ${ }^{11}$

Hal ini berkaitan dengan kesiapan yang dimiliki oleh ibu mulai dari persalinan sampai dengan menghadapi masa pascasalin, mulai kecemasan menghadapi persalinan, keselamatan dirinya dan bayinya yang akan berlanjut sampai pascasalin mengenai perawatan bayi dan cara menyusui, sedangkan pada ibu multipara biasanya depresi terjadi karena adanya pikiran tentang bagaimana perawatan anak, seperti kesejahteraan, pendidikan dan asuransi. Hasil penelitian lain menyebutkan beberapa faktor risiko depresi pada masyarakat timur adalah jenis kelamin bayi dan grandemultipara. ${ }^{14}$ Keadaan ekonomi yang kurang mendukung dapat menimbulkan stres di keluarga yang mempengaruhi depresi ibu setelah melahirkan. Selain itu bisa berasal dari keadaan emosional, seperti konflik dalam keluarga. Bahkan kegiatan yang seharusnya mendatangkan kebahagiaan seperti kelahiran bayi bisa menimbulkan tekanan karena mereka menimbulkan perubahan baru dalam hidup seorang wanita.
Penelitian ini menunjukkan bahwa depresi pascasalin sebagian besar terdapat pada responden yang memiliki status sosial ekonomi rendah yaitu sebanyak tujuh responden $(29,2 \%)$, dan hanya dua responden $(6,3 \%)$ yang status ekonominya tinggi. Hal ini menunjukkan bahwa kejadian depresi pascasalin di Wilayah Kerja Puskesmas Kayamanya dipengaruhi oleh tingkat status ekonomi $(p=0,030)$. Hasil penelitian ini sejalan dengan penelitian yang dilakukan oleh Fatmah Ibrahim tahun 2012 yang mengatakan bahwa ada hubungan antara status sosial ekonomi dengan depresi postpartum pada ibu. ${ }^{6}$ Hasil penelitian ini tidak sesuai dengan penelitian yang pernah dilakukan oleh Depika Goyal dan teman-temannya yang menunjukkan bahwa sosial ekonomi termasuk pendapatan memiliki hubungan dengan depresi pada akhir kehamilan, 2 bulan dan 3 bulan pascasalin tetapi tidak pada 1 bulan pertama pascasalin. ${ }^{9}$

Pengukuran depresi pascasalin pada penelitian ini dilakukan pada 7 hari pascasalin, dimana pada saat itu ibu/ keluarga masih banyak mendapat bantuan dari orang-orang terdekat seperti orangtua, saudara atau tetangga. Penelitian lain juga menunjukkan bahwa status ekonomi akan memiliki hubungan dengan kejadian depresi pascasalin jika digabungkan dengan faktor yang lain. ${ }^{3}$ Faktor umur dan pendidikan dalam penelitian ini memiliki nilai $\mathrm{p}>0,05$ sehingga dapat dikatakan kedua faktor tersebut tidak berhubungan dengan kejadian depresi pascasalin.

Umur responden, pada penelitian ini, tidak berhubungan dengan depresi pascasalin. Hal ini sesuai dengan penelitian yang dilakukan di Sidoarjo dan Kalkota bahwa umur tidak berhubungan dengan depresi pascasalin. ${ }^{8,}{ }^{15}$ Faktor usia 
perempuan yang bersangkutan saat kehamilan dan persalinan seringkali dikaitkan dengan kesiapan mental perempuan tersebut untuk menjadi seorang ibu ditambah lagi dengan kepercayaan masyarakat bahwa saat yang tepat bagi seseorang perempuan untuk melahirkan pada usia antara 20-30 tahun, dan hal ini mendukung masalah periode yang optimal bagi perawatan bayi oleh seorang ibu.

Penelitian lain yang menunjukkan bahwa ibu dengan usia kurang dari 25 tahun memiliki risiko terjadi depresi. ${ }^{16}$ Sedangkan pada penelitian ini, sebagian besar responden berusia 20-35 tahun. Tingkat pendidikan merupakan salah satu faktor yang turut berperan terhadap kejadian depresi postpartum. Hasil uji statistik menunjukkan bahwa pendidikan memiliki nilai $\mathrm{p}>0,05$ yang berarti tidak ada hubungan antara pendidikan dengan depresi pascasalin.

Penelitian ini tidak sesuai dengan penelitian sebelumnya yang dilakukan oleh Devi Kurniasari, 2014 di Rumah Sakit Umum Ahmad Yani Metro yang menunjukkan bahwa terdapat pengaruh yang signifikan pendidikan terhadap depresi pascasalin dengan nilai $\mathrm{p}=0,017 .{ }^{17}$ Berdasarkan penelitian tersebut terlihat bahwa ibu dengan pendidikan tinggi akan lebih mudah untuk menerima informasi ataupun bimbingan yang diberikan untuk mengatasi masalahnya, misalnya dengan psikoedukasi. $^{5}$ Penelitian lain yang menunjukkan bahwa pendidikan dan dukungan keluarga, ibu yang berpendidikan rendah berpeluang 11,6 kali untuk terjadi depresi pascasalin dibandingkan dengan ibu yang berpendidikan tinggi. ${ }^{9}$ Hal ini terjadi disebabkan mungkin karena seorang perempuan yang berpendidikan tinggi menghadapi tekanan sosial dan konflik peran, antara tuntutan sebagai perempuan yang memiliki dorongan untuk bekerja atau melakukan aktivitasnya di luar rumah, dengan peran mereka sebagai ibu rumah tangga dan orang tua dari anak-anak mereka.

Perilaku yang diadopsi oleh individu bisa dihasilkan dari pendidikan formal, namun pada sebagian orang pendidikan tidak mempengaruhi sikap hal tersebut lebih besar berasal dari lingkungan yang diterima oleh individu. Menurut penulis baik pendidikan tinggi maupun pendidikan rendah berpeluang untuk mengalami depresi pascasalin, tergantung bagaimana individu tersebut mengantisipasi masalah yang terjadi. Pendidikan merupakan gambaran kondisi masyarakat yang dapat menjadi salah satu penyebab terjadi depresi kehamilan dan pascasalin.

Sebagian besar responden, pada penelitian ini, tingkat pendidikannya SMA/ sederajat sehingga informasi yang mereka dapatkan sebagian besar hanya dari lingkungan, dan sangat sedikit informasi yang berasal dari media elektronik. Dalam hal ini bidan diharapkan dalam melakukan asuhan kebidanan juga memperhatikan tingkat pendidikan dan ekonomi ibu, sehingga apa yang disampaikan oleh bidan baik yang berupa pendidikan kesehatan atau konseling kesehatan dapat diterima dan dimengerti oleh ibu serta informasi yang diberikan harus menyeluruh. Faktor pendidikan dan status ekonomi merupakan gambaran keadaan masyarakat dan tidak bisa dirubah, sehingga apabila faktor tersebut mempengaruhi kejadian depresi kehamilan maka dengan kondisi yang masyarakat 
yang sudah ada juga dapat berpengaruh terhadap depresi pascasalin.

\section{Hubungan Dukungan Sosial dengan Depresi Pascasalin}

Dukungan sosial merupakan salah satu faktor yang turut berperan terhadap kejadian depresi pascasalin. Setelah melahirkan biasanya wanita mengalami keadaan lemah fisik dan mental sehingga membutuhkan dukungan bantuan dan perhatian yang lebih dari lingkungannya, baik itu dari suami, keluarga maupun teman. Kurangnya dukungan sosial dapat mempengaruhi muncul dan berkembangnya kondisi depresi postpartum. Hasil penelitian ini menunjukkan bahwa depresi pascasalin sebagian besar terdapat pada responden yang kurang mendapat dukungan sosial dari keluarga yaitu sebanyak 5 responden $(35,7 \%)$ dan hanya 4 responden $(9,5 \%)$ yang mendapatkan dukungan sosial yang cukup dari suami dan dari keluarga sendiri.

Dukungan memberi pengaruh dalam mengurangi depresi yang dihadapi wanita pada masa postpartum. Wanita yang merasa dihargai, diperhatikan dan dicintai oleh suami dan keluarganya tentunya tidak akan merasa diri kurang berharga. Sehingga salah satu ciri dari seseorang menderita depresi dapat dihambat. Wanita yang kurang mendapatkan dukungan sosial tentunya akan lebih mudah merasa dirinya tidak berharga dan kurang diperhatikan oleh suami maupun keluarga, sehingga wanita yang kurang mendapat dukungan sosial pada masa postpartum lebih mudah untuk mengalami depresi. ${ }^{18}$

Berdasarkan hasil uji statistik menunjukkan bahwa dukungan sosial keluarga mempunyai $\mathrm{p}=0,035$ dengan nilai
OR 5,278 yang berarti bahwa jika dukungan sosial keluarga yang diterima pada pascasalin rendah maka akan berisiko 5,278 kali untuk terjadi depresi pascasalin dibandingkan dengan ibu yang mendapat dukungan sosial keluarga tinggi. Dukungan sosial terutama dari keluarga sangat dibutuhkan oleh ibu pascasalin terutama pada beberapa minggu setelah persalinan, terutama oleh ibu primipara yang belum memiliki pengalaman sebelumnya, karena pada masa ini keadaaan fisik ibu masih lemah dan masih banyak membutuhkan bantuan orang lain baik dalam hal perawatan dirinya selama pascasalin maupun perawatan bayinya. Hal ini sejalan dengan penelitian yang dilakukan oleh Fatmah Ibrahim di RSIA Pertiwi Makassar bahwa terdapat hubungan antara dukungan suami dengan kejadian depresi postpartum $(\mathrm{p}=0,000) .{ }^{6}$ Penelitian serupa yang dilakukan oleh Kurniasari menunjukkan bahwa ada hubungan yang bermakna antara dukungan suami dengan kejadian post partum blues di Rumah Sakit Umum Ahmad Yani Metro tahun 2014. ${ }^{17}$

Dukungan keluarga yang dimaksud adalah komunikasi dan hubungan emosional yang baikdan hangat dengan orangtua, terutama ibu, sedangkan dari penelitian ini didapatkan data bahwa rendahnya atau ketidakpastian dukungan suami dan keluarga akan meningkatkan kejadian depresi postpartum. ${ }^{19}$ Penelitian sebelumnya menunjukkan bahwa dukungan yang diberikan oleh keluarga/ suami terbukti dapat menurunkan terjadinya depresi pascasalin. ${ }^{20}$ Selain keluarga atau suami, lingkungan juga berperan dalam memberikan dukungan kepada ibu hamil dan pascasalin. Lingkungan sosial salah satunya adalah 
teman atau tetangga, mereka dapat memberikan dukungan berupa informasi atau kebiasaan yang harus dilakukan pada kehamilan, walaupun tidak semua informasi yang diberikan tepat, karena informasi tersebut lebih didasarkan pada pengalaman masing-masing individu. Beberapa informasi yang diberikan terkadang tidak sesuai dengan informasi yang diterima oleh ibu hamil dari tenaga kesehatan, sehingga ibu merasa bingung dengan adanya perbedaan informasi yang diterima. Semakin banyak informasi yang diterima dan bertentangan maka akan membuat ibu semakin cemas/ khawatir.

Dukungan yang dapat diberikan oleh suami, teman dan bidan dapat berupa dukungan emosional, dukungan praktis serta dukungan sosial. Ketiga komponen tersebut terbukti memiliki hubungan yang sangat signifikan terhadap kejadian depresi yang diukur dengan menggunakan skala depresi pascasalin Edinburgh dengan skor $>9$ atau $>12 .^{3}$ Dalam hal ini peran bidan sangat penting, bidan merupakan salah satu bagian dari sumber dukungan sosial, sehingga dalam melakukan asuhan kebidanan hendaknya tidak hanya berfokus pada kesehatan fisik ibu tetapi juga ikut serta memberikan dukungan sosial dan kesehatan mental ibu. Misalnya dengan memberikan informasi mengenai pola hidup sehat, perubahan fisik dan psikologis yang terjadi, membantu dalam mengatasi kecemasan yang dirasakan oleh ibu serta menyampaikan kepada suami untuk ikut serta dalam menjaga kesehatan ibu dan bayinya. ${ }^{21}$

\section{KESIMPULAN}

1. Faktor demografi yang meliputi paritas dan sosial ekonomi berhubungan dengan depresi pascasalin.
2. Dimensi dukungan sosial keluarga, teman, dan bidan berhubungan dengan depresi pascasalin.

3. Faktor yang paling dominan dengan depresi pascasalin adalah dukungan bidan.

\section{DAFTAR PUSTAKA}

(1) Patel V. Postnatal depression and Infant Growth and Development in Low Income Countries: A Cohort Study from Goa, India. Arch Dis Child 2003: 88 (1): 34-37. (Online) http://adc.bmj.com/cgi/doi/10.1136/a dc.88.1.34 [Diakses

(2) Regina, J.K.P.K. Hubungan antara depresi postpartum dengan kepuasan seksual pada ibu primipara. Psychological Journal. 2001: 1 (16): 14.

(3) Eastwood J.G., Jalaludin B.B., Kemp L.A., \& Barnett B.E. Relationship of Postnatal Depressive Symptoms to Infant Temperament, Maternal Expectations, Sosial Support and Other Potential Risk Faktors: Findings from A Large Australian Cross-Sectional Study. BMC Pregnancy and Childbirth. 2012: 12 (148): $1-11$. https://bmcpregnancychildbirth.biom edcentral.com/articles/10.1186/14712393-12-148 [Diakses 12 December 2012]

(4) Montazeri A., Torkan B., \& Omidvari S. The Edinburgh Postnatal Depression Scale (EPDS): Translation and Validation Study of The Iranian Version. BMC Psychiatry 2007: 7 (11). (Online) https://bmcpsychiatry.biomedcentral. com/articles/10.1186/1471-244X-711 [Diakses 
(5) Nazara, Yafeti. Efektivitas Psikoedukasi Terhadap Pencegahan Depresi Pascasalin (Penelitian di Pelayanan Kesehatan Kabupaten Nias, Sumatera Utara). Majalah Obstetri Ginekologi Indonesia. 2009:33 (4): 216-218

(6) Ibrahim F. Faktor-Faktor Yang Berhubungan dengan Depresi Postpartum di RSIA Pertiwi Makassar Tahun 2012. 2012. (Online)

http://repository.unhas.ac.id/bitstrea $\underline{\mathrm{m} /}$

handle/123456789/4250/Fatma\%20I brahim\%20(K11108297).pdf?sequen $\mathrm{ce}=1$ [Diakses....

(7) Dibaba Y., Fantahun M., \& Hindin M.J. The Assosiation of Unwanted Pregnancy adn Sosial Support with Depressive symthoms in pregnancy : Evidance from Rural Southwestern Ethiophia. BMC Pregnancy and Childbirth. 2013; 13 (135): 1-8. (Online)

https://bmcpregnancychildbirth.biom edcentral.com/articles/10.1186/14712393-13-135 [Diakses....

(8) Anuradha G, Sebanti G. Evaluation of Post Partum Depression in a Tertiary Hospital Obstetrics and Gynecology of India. 2011: 61 (5): 528-530. $\quad$ https://www.ncbi.nlm. nih.gov/pmc/articles/PMC3257346/p df/13224 2011 Article 77.pdf.

[Diakses 29 Oktober 2011]

(9) Goyal D, Gay C, Lee KA. How much does Low Socioeconomic Status Increase the Risk of Prenatal and Postpartum Depressive Symptoms in First Time Mothers? Womens Health Issues. 2010; 20 (2): 96-104. https://www.ncbi.nlm.nih.gov/ pmc/articles/PMC2835803/

[Diakses....

(10) Saleh E-S, El-Bahei W, El-Hadidy MA, Zayed A. Predictors Of Postpartum Depression In A Sample Of Egyptian Women. Neuropsychiatr Dis Treat. 2012; 9: 15-24. (online). https://www.ncbi.nlm.nih.gov/pmc/ar ticles/PMC3533691/ [Diakses 21 Desember 2012].

(11) Soep. Pengaruh Intervensi Psikoedukasi Dalam Mengatasi Depresi Postpartum Di RSU Dr. Pirngadi Medan Sumatera Utara: Universitas Sumatera Utara; 2009. (Online)

http://repository.usu.ac.id/bitstream/h andle $/ 123456789 / 6885 /$ ? sequence $=1$

[Diakses....

(12) Dennis L.C. \& Queen K.M.. The Relationship between Infant-Feeding Outcomes and Postpartum Depression: a Qualitative Systematic Review Pediatrics. 2009: 123 (4):736-751.

(Online)

http://pediatrics.aappublications.org/ content/123/4/e736.short [Diakses....

(13) Handoyo, H.L.L. Penerapan Skala Edinburgh sebagai Alat Deteksi Risiko. Depresi Postpartum pada Primipara dan Multipara. Jurnal Ilmiah Kesehatan Keperawatan. Universitas Jendral Soedirman 2007: 3 (3): 163-171.

(14) Goker A., Yanikkerem E., Demet M.M., Dikayak S., Yildirim Y., \& Koyuncu F.M. Postpartum Depression: Is Mode of Delivery a Risk Faktor? Obstetrics and Gynecology. 2012: 1-6. (Online) https://www.ncbi.nlm.nih.gov/pmc/ar 
ticles/ PMC3530850/ [Diakses 3

Desember 2012]

(15) Laili U. Hubungan Antara Faktor Demografi dan Dukungan Sosial dengan Depresi Kehamilan dan Pascasalin (Studi di Wilayah Puskesmas Urangagung Kabupaten Sidoarjo). (Tesis). Bandung: Universitas Padjajaran; 2014

(16) Sword W., Landy C.K., Thabane L., Watt S., Krueger P., Farine D., et al. Is Mode of Delivery Associated with Postpartum Depression at 6 Weeks: A Prospective Cohort Study. British Journal of Obstetrics and Gynaecology. 2011: 118 (8): 966-77. (Online) http://onlinelibrary.wiley. com/doi/10.1111/j.1471-0528.2011 .02950.x/full [Diakses 13 April 2011]

(17) Kurniasari, D dan Astuti, YA. Hubungan Antara Karakteristik Ibu, Kondisi Bayi dan Dukungan Sosial Suami dengan Postpartum Blues pada Ibu Dengan Persalinan SC Di Rumah Sakit Umum Ahmad Yani Metro Tahun 2014. Jurnal Kesehatan Holistik. 2015: 9 (3).

(18) Urbayatun. Dukungan Sosial dan Kecenderungan Depresi Postpartum pada Ibu Primipara di Daerah Gempa Bantul. Jurnal Humanitas. 2010: 3 (2).. (Online) http://download.portal garuda.org/article.php?article $=12412$ $\underline{6 \& v a l=5536}[$ Diakses $\ldots .$. Agustus 2010]

(19) Elvira S. Depresi Pasca Persalinan. Jakarta: Balai Penerbit FKUI; 2006.

(20) Alfiben W.G.S.D.E. Efektivitas Peningkatan Dukungan Suami dalam Menurunkan Terjadinya Depresi Pascasalin. Obstet Ginekol Indonesia. 2000: 24 (4): 208-214
(21) Taufik. Psikologi untuk Kebidanan dari Teori ke Praktek. Surakarta: Estview; 2010. 